Jurnal Satyagraha, Vol. 02, No. 02, Agustus 2019 - Januari 2020 ISSN :2620-6358

\title{
PENGARUH MOTIVASI DAN LINGKUNGAN KERJA TERHADAP KINERJA PEGAWAI KANTOR DESA ABANG KECAMATAN ABANG KABUPATEN KARANGASEM
}

\author{
I Wayan Sukada \\ ${ }^{1}$ Program Studi Manajemen, FakultasEkonomi, UniversitasMahendradatta \\ Jl. Ken Arok No 12, Peguyangan Denpasar Utara, Bali 80115 \\ Email: wayansukada13@gmail.com
}

\begin{abstract}
Abstrak-Motivasi ini sangat berkaitan dengan kebutuhan, sehingga manajemen organisasi harus lebih menaruh perhatian terhadap kebutuhan pegawai agar bisa memotivasi dengan baik. Organisasi dapat menciptakan lingkungan kerja dengan baik dan sesuai harapan pegawai, dengan adanya jaminan hari tua dan masa depan yang lebih baik, lingkungan pekerjaan yang konduktif dengan adanya pencahayaan lampu di ruangan yang lebih baik akan membuat mereka merasa nyaman dalam bekerja. Faktor motivasi dan lingkungan kerja akan menjadi faktor yang dapat menjadikan pegawai mencapai kepuasan dalam bekerja sehingga dapat meningkatkan kinerja yang berarti bagi organisasi.Tujuan yang ingin dicapai dari penelitian ini adalah : 1) Untuk mengetahui pengaruh motivasi terhadap kinerja pegawai Kantor Desa Abang.2) Untuk mengetahui pengaruh lingkungan kerja terhadap kinerja pegawai pada Kantor Desa Abang. 3) Untuk mengetahui pengaruh Motivasi dan Lingkungan Kerja secara bersama-sama terhadap Kinerja Pegawai Kantor Desa Abang.Pada penelitian ini yang menjadi variabel bebas adalah Motivasi (X1) dan Lingkungan Kerja (X2).variabel terikat adalah Kinerja Pegawai (Y).Sumber data yang dipakai yaitu sumber data primerdan sekunder, dengan metode pengumpulan data wawanara, observasi dan kuisioner.

Data dalam penelitian ini memenuhi syarat normal probability plot yang berarti bahwa tidak terdapat korelasi antar variabel bebas yang lebih besar dari 95\%. Dari hasil regresi berganda diperoleh $\mathrm{a}=5,323, \mathrm{~b} 1=0,306$ dan $\mathrm{b} 2=0,305$. Dengan demikian persamaan regresinya adalah : $\mathrm{Y}=5,323+0,306 \mathrm{X} 1+0,305 \mathrm{X} 2$. Dengan panduan tabel koefisien korelasi, dapat dijelaskan bahwa terdapat hubungan positif antara pengaruh Motivasi kerja (X1) dan Lingkungan Kerja (X2) terhadap Kinerja Pegawai (Y) yaitu terdapat hubungan yang tinggi atau sangat kuat, karena terletak antara 0,800 sampai dengan 1,199yaitu $r=0.825$. Artinya semakin besar strategi pemasaran yang diberikan, maka tinggi pula penjualannya.D = $68,1 \%$, ini menunjukan bahwa Motivasi kerja dan Lingkungan Kerja mempunyai pengaruh yang cukup kuat, yaitu $68,1 \%$, dalam upaya meningkatkan Kinerja Pegawai.Diperoleh f-test sebesar 28,766 pada daerah penolakan Ho. Dimana f-test lebih besar daripada f-tabel. Pengaruh Pengaruh Motivasi kerja(X1) Terhadap Kinerja Pegawai $(Y)$ diperoleh t-test $=5,228$. Pengaruh Lingkungan Kerja $(X 2)$ terhadap Kinerja Pegawai(Y) diperoleh t-test $=6,581$. Dari kedua analisis t-test di atas, dapat dijelaskan bahwa Motivasi dan Lingkungan Kerja memiliki pengaruh yang kuat terhadap Kinerja Pegawai.
\end{abstract}


Katakunci:kinerja pegawai, lingkungan kerja, dan motivasi

Abstract-This motivation is closely related to needs, so that the management of the organization must pay more attention to the needs of employees so they can motivate well. Organizations can create a work environment that is good and in line with employee expectations, with guaranteed old age and a better future, a conductive work environment with better lighting in the room will make them feel comfortable at work. Motivation factors and work environment will be a factor that can make employees achieve satisfaction in working so that it can improve performance that is meaningful to the organization. The objectives to be achieved from this research are: 1) To determine the effect of motivation on the performance of Abang Village Office employees.2) To determine the effect of the work environment on employee performance at the Abang Village Office. 3) To find out the effect of Motivation and Work Environment together on the Office Staff Performance of Abang Village. In this study the independent variables are Motivation (X1) and Work Environment (X2). the dependent variable is Employee Performance $(Y)$. Data sources used are primary and secondary data sources, with interview data collection methods, observation and questionnaires.

The data in this study meet the normal probability plot requirements which means that there is no correlation between the independent variables greater than $95 \%$. From the results of multiple regression obtained $a=5.323, b 1=0.306$ and $b 2=0.305$. Thus the regression equation is: $Y=5.323+0.306 X 1+0.305 X 2$. With the correlation coefficient table guide, it can be explained that there is a positive relationship between the effect of work motivation (X1) and Work Environment (X2) on Employee Performance ( $Y$ ) that is a high or very strong relationship, because it is located between 0.800 to 1.199 ie $r=0.825$. This means that the bigger the marketing strategy is given, the higher the sales. $D=68.1 \%$, this shows that work motivation and work environment have a fairly strong influence, namely $68.1 \%$, in an effort to improve employee performance. Obtained a f-test of 28,766 in the rejection area of Ho. Where the f-test is greater than the $f$ table. The Effect of Work Motivation Effect (X1) on Employee Performance (Y) obtained t-test $=$ 5.228. Effect of Work Environment $(X 2)$ on Employee Performance $(Y)$ obtained $t$-test $=6.581$. From the two $t$-test analyzes above, it can be explained that Motivation and Work Environment have a strong influence on Employee Performance.

Keywords:Environment, Motivation, and Performance 


\section{PENDAHULUAN}

Salah satu hal yang harus jadi perhatian utama perusahaan/organisasi adalah mengenai bagaimana menjaga dan mengelola motivasi pegawaidalam bekerja agar selalu fokus pada tujuan perusahaan/organisasi. Motivasi adalah dorongan dasar yang menggerakkan seseorang atau keinginan untuk mencurahkan segala tenaga karena adanya suatu tujuan. Motivasi muncul dari dalam diri manusia karena dorongan oleh adanya unsur suatu tujuan. Tujuan ini menyangkut soal kebutuhan dapat dikatakan bahwa tidak akan ada suatu motivasi apabila tidak dirasakan adanya suatu kebutuhan. Salah satu yang mempengaruhi motivasi pegawai dalam bekerja adalah lingkungan kerja dimana pegawai tersebut bekerja seperti hal yang diungkapkan oleh Stephan P.Robbins (2001) bahwa kepuasan kerja salah satunya ditentukan oleh kondisi kerja yang mendukung, lingkungan kerja yang mendukung akan membuat para pegawai merasa nyaman dan bersemangat dalam melakukan kewajibannya, sebaliknya lingkungan kerja yang tidak mendukung akan membuat pegawai tidak bersemangat dan merasa tidak nyaman, jika demikian akan berpengaruh langsung terhadap motivasi kerja pegawai. Jadi lingkungan kerja yang baik akan mempengaruhi gairah dan semangat kerja pegawai saat bekerja.

Lingkungan kerja yang nyaman bagi pegawai dapat meningkatkan kinerja seseorang. Sebaliknya lingkungan kerja yang tidak memadai akan dapat menurunkan kinerja dan akhirnya menurunkan motivasi kerja pegawai. Motivasi dapat dipandang sebagai perubahan energi dalam diri seseorang yang ditandai dengan munculnya feeling, dan didahului dengan tanggapan terhadap adanya tujuan.

Sebagai obyek penelitian adalah Kantor Desa Abang merupakan salah satu organisasi yang dibentuk untuk melaksanakan tugastugas pemerintahan, pengaturan, dan pemberian pelayanan kepada masyarakat dibidang pemerintahan, dalam melakukan aktivitasnya sangat tergantung pada faktor sumber daya manusia. Peran motivasi akan dapat berpengaruh bagi pegawai untuk meningkatkan kinerja. Motivasi ini sangat berkaitan dengan kebutuhan, sehingga manajemen organisasi harus lebih menaruh perhatian terhadap kebutuhan pegawai agar bisa memotivasi dengan baik. Organisasi dapat menciptakan lingkungan kerja dengan baik dan sesuai harapan pegawai, dengan adanya jaminan hari tua dan masa depan yang lebih baik, lingkungan pekerjaan yang konduktif dengan adanya pencahayaan lampu di ruangan yang lebih baik akan membuat mereka merasa nyaman dalam bekerja. Faktor motivasi dan lingkungan kerja akan menjadi faktor yang dapat menjadikan pegawai mencapai kepuasan dalam bekerja sehingga dapat meningkatkan kinerja yang berarti bagi organisasi.

Motivasi berasal dari kata latin "movere" yang berarti dorongan atau daya penggerak.Motivasi adalah daya pendorong yang mengakibatkan seseorang anggota organisasi mau dan rela untuk mengarahkan kemampuan dalam bentuk keahlian atau ketrampilan tenaga dan waktunya untuk menyelenggarakan berbagai kegiatan yang menjadi 
tanggung jawabnya dan menunaikan kewajibannya, dalam rangka pencapaian tujuan dan berbagai sasaran organisasi yang telah ditentukan sebelumnya Sondang Siagian (2003). Motivasi merupakan hasrat di dalam seseorang yang menyebabkan orang tersebut melakukan tindakan Robert L. Mathis dan John H. Jackson (2006). Motivasi karyawan mempengaruhi kinerja, dan sebagian tugas seorang manajer adalah menyalurkan motivasi menuju pencapaian tujuan-tujuan organisasional.

Motivasi adalah serangkaian sikap dan nilai-nilai yang mempengaruhi individu untuk mencapai hal yang spesifik sesuai dengan tujuan individu. Sikap dan nilai tersebut merupakan suatu kekuatan untuk mendorong individu bertingkah laku dalam mencapai tujuan. Dorongan tersebut terdiri dari dua komponen, yaitu: arah perilaku kerja (kerja untuk mencapai tujuan), dan kekuatan perilaku (sebagai kuat usaha individu dalam bekerja). Motivasi meliputi perasaan unik, pikiran dan pengalaman masa lalu yang merupakan bagian dari hubungan internal dan eksternal perusahaan. Winardi (2002) mengemukakan bahwa "istilah motivasi (motivation) berasal dari perkataan latin yakni movere yang berarti menggerakkan (tomove)". Motivasi adalah pemeberian daya penggerak yang menciptakan kegairahan kerja seseorang agar mereka mau bekerja dengan segala daya upayanya untuk mencapai kepuasan, Hasibuan (2007). Ishak dan Hendri mengemukakan bahwa "motivasi sebagai suatu hal pokok yang menjadi dorongan setiap motif untuk bekerja". Motivasi sering kali diartikan pula sebagai faktor pendorong perilaku seseorang. Menurut Robbins (2008) motivasi sebagai proses yang menjelaskan intensitas, arahan dan ketekunan seorang individu untuk mencapai tujuan.

Berdasarkan pendapat tersebut dapat disimpulkan bahwa :

1. Motivasi kerja merupakan bagian yang penting dalam suatu organisasi yang berfungsi sebagai alat untuk pencapaian tujuan atau sasaran yang ingin dicapai.

2. Motivasi kerja mengandung dua tujuan utama dalam diri individu yaitu untuk memenuhi kebutuhan atau keinginan pribadi dan tujuan organisasi.

3. Motivasi kerja yang diberikan kepada seseorang hanya efektif manakala di dalam diri seseorang itu memiliki kepercyaan atau keyakinan untuk maju dan berhasil dalam organisasi.

Pada penelitian ini penelitian menggunakan indikator motivasi dari teori Maslow. Teori hirarki kebutuhan dari Abraham Maslow menurut Sofyandi dan Garbiwa (2007), terdiri dari :

a. Kebutuhan fisiologis (Physiological-need)

Kebutuhan fisiologis merupakam hirarki kebutuhan manusia yang paling dasar yang merupakan kebutuhan untuk dapat hidup seperti makan, minum, perumahan, oksigen, sex dan sebagainya.

b. Kebutuhan rasa aman (Safetyneed) 
Apabila kebutuhan fisiologis relatif sudah terpuaskan, maka muncul kebutuhan yang kedua yaitu kebutuhan akan rasa aman. Kebutuhan akan rasa aman ini meliputi keamanan akan perlindungan dari bahaya kecelakaan kerja, jaminan akan kelangsungan pekerjaannya dan jaminan akan hari tuanya pada saat mereka tidak lagi bekerja.

c. Kebutuhan sosial (Social-need) Jika kebutuhan fisiologis dan rasa aman telah terpuaskan secara minimal maka akan muncul kebutuhan sosial yaitu kebutuhan untuk persahabatan afiliasi dana interaksi yang lebih erat dengan orang lain. Organisasi akan berkaitan dengan kebutuhan adanya kelompok kerja yang kompak, supervisi yang baik, rekreasi bersama dan sebagainya.

d. Kebutuhan penghargaan (Esteem-need)

Kebutuhan ini meliputi kebutuhan keinginan untuk dihormati, dihargai atas prestasi seseorang, pengakuan atas kemampuan dan keahlian seseorang serta efektifitas kerja seseorang.

e. Kebutuhan aktualisasi diri (Seftactualization need)

Aktualisasi diri merupakan hirarki kebutuhan dari Maslow yang paling tinggi. Aktualisasi diri berkaitan dengan proses pengembangan potensi yang sesungguhnya dari seseorang. Kebutuhan untuk menunjukkan kemampuan, keahlian dan potensi yang dimiliki seseorang.

Lingkungan kerja dalam suatu perusahaan perlu diperhatikan, hal ini pegawai. Lingkungan kerja yang kondusif dapat meningkatkan Kinerja Pegawai dan sebaliknya, lingkungan kerja yang tidak memadai akan dapat menurunkan Kinerja Pegawai. Kondisi lingkungan kerja dikatakan baik apabila manusia dapat melaksanakan kegiatan secara optimal, sehat, aman dan nyaman. Kesesuaian lingkungan kerja dapat dilihat akibatnya dalam jangka waktu yang lama. Lingkungan kerja yang kurang baik dapat menuntut tenaga kerja dan waktu yang lebih banyak dan tidak mendukung rancangan sistem kerja yang efisen.

Menurut Robbins

lingkungan adalah lembaga-lembaga atau kekuatan-kekuatan diluar yang berpotensi mempengaruhi kinerja organisasi, lingkungan dirumuskan menjadi dua yaitu lingkungan umum dan lingkungan khusus. Lingkungan umum adalah segala sesuatu di luar organisasi yang memiliki potensi untuk mempengaruhi organisasi. Lingkungan ini berupa kondisi sosial dan teknologi. Sedangkan lingkungan khusus adalah bagian lingkungan yang secara langsung berkaitan dengan pencapaian sasaran-sasaran sebuah organisasi. Menurut Basuki dan Susilowati (2006) lingkungan kerja adalah segala sesuatu yang berada di lingkungan yang dapat mempengaruhi baik secara langsung maupun tidak langsung seseorang atau sekelompok orang di dalam melaksanakan aktivitasnya.

Dari pendapat para ahli dapat disimpulkan bahwa lingkungan kerja adalah berupa fisik maupun nonfisik yang dapat mempengaruhi karyawan saat bekerja. Jika lingkungan kerja yang kondusif maka karyawan bisa aman,nyaman dan jika lingkungan 
kerja tidak mendukung maka karyawan tidak bisa aman dan nyaman.

Indikator-indikator lingkungan kerja oleh Nitisemito (1992) yaitu sebagai berikut :

1. Suasana Kerja

2. Hubungan dengan rekan kerja yaitu hubungan dengan rekan

3. Tersedianya fasilitas kerja Sedangkan menurut Sedarmayanti (2009) indikatorindikator lingkungan kerja yaitu sebagai berikut :

1. Penerangan/cahaya di tempat kerja

2. Sirkulasi udara di tempat kerja

3. Kebisingan di tempat kerja

4. Bau tidak sedap di tempat kerja

5. Kemanan di tempat kerja

Dari dua pendapat yang berbeda peneliti mengambil indikator yaitu suasana kerja, hubungan dengan rekan kerja, tersedianya fasilitas kerja, penerangan, sirkulasi, kebisingan, bau tidak sedap dan keamanan.

Kinerja pegawai menurut Roziqin (2010) adalah sebagai keseluruhan proses bekerja dari individu yang hasilnya dapat digunakan landasan untuk menentukanapakah pekerjaan individu tersebut baik atau sebaliknya, sedangkan menurut Sandy (2005) memberikan pengertian bahwa kinerja atau prestasi kerja adalah hasil atau tingkat keberhasilan seseorang secara keseluruhan selama periode tertentu di dalam melaksanakan tugas dibandingkan dengan berbagai kemungkinan, seperti standar hasil kerja, target atau sasaran atau kriteria yang telah ditentukan terlebih dahulu dan disepakati bersama.
Fahmi (2010) definisi kinerja adalah hasil yang diperoleh oleh suatu organisasi baik organisasi tersebut bersifat profit oriented dan non profit oriented yang dihasilkan selama satu periode waktu. Supriyono (2010), mengemukakan bawha kinerja adalah suatu hasil yang dicapai seseorang dalam melaksanakan tugas-tugas yang diberikan kepadanya yang didasarkan atas kecakapan, pengalaman dan kasanggupan serta waktu.

Hasil kerja yang dapat dicapai oleh seorang atau sekelompok orang dalam suatu organisasi, sesuai dengan wewenang dan tanggung jawab masing-masing dalam rangka upaya mencapai tujuan organisasi bersangkutan secara lega;, tidak melanggar hukum dan sesuai dengan moral maupun etika. Zainur (2010) mengemukakan kinerja sebagai suatu perwujudan kerja aparatur yang selanjutnya akan dijadikan dasar penilaian atas tercapai atau tidaknya target dan tujuan suatu organisasi pemerintahan kinerja meliputi hasilhasil yang telah dicapai oleh pegawai dan melaksanakan tugas yang diberikan. Berdasarkan beberapa pendapat di atas dapat disimpulkan bahwa kinerja pegawai adalah hasil kerja dari seseorang pegawai selama bekerja dalam menjalankan tugastugas pokok jabatannya yang dapat dijadikan sebagai landasan apakah pegawai itu bisa dikatakan mempunyai prestasi kerja yang baik atau sebaliknya.

Indikator kinerja menurut Robert dan John (2006), antara lain sebagai berikut :

a) Kuantitas dari hasil,

b) Kualitas dari hasil,

c) Ketetapan waktu dari hasil, 
d) Kehadiran, yaitu ada tidaknya pegawai di dalam kantor ketika memasuki jam-jam kerja.

e) Kemampuan bekerja sama,

Hipotesis merupakan jawaban sementara pernyataan-pernyataan yang dikemukakan dalam perumusan masalah. Kaitannya dengan pengaruh motivasi kerja dan lingkungan kerja terhadap kinerja pegawai di atas, maka rumusan hipotesis dalam penelitian ini adalah :

H1:Diduga motivasi kerja signifikan terhadap kinerja pegawai Kantor Desa Abang Kecamatan Abang Kabupaten Karangasem.

H2: Diduga lingkungan kerja berpengaruh positif dan signifikan terhadap kinerja pegawai Kantor Desa Abang Kecamatan Abang Kabupaten Karangasem.

H3:Diduga motivasi kerja, dan lingkungan kerja secara simultan berpengaruh terhadap kinerja pegawai pada Kantor Desa Abang Kecamatan Abang Kabupaten Karangasem.

Permasalahan yang telah diuraikan diatas, maka rumusan masalahnya adalah :

1) Bagaimanakah pengaruh motivasi dan lingkungan kerja secara parsial terhadap kinerja pegawai Kantor Desa Abang ?

2) Bagaimanakah pengaruh motivasi dan lingkungan kerja secara simultan terhadap kinerja pegawai Kantor Desa Abang ?

Tujuan yang ingin dicapai dari penelitian ini adalah :

a. Untuk mengetahui pengaruh motivasi terhadap kinerja pegawai Kantor Desa Abang.

b. Untuk mengetahui pengaruh lingkungan kerja terhadap kinerja pegawai pada Kantor Desa Abang.

c. Untuk mengetahui pengaruh Motivasi dan Lingkungan Kerja secara bersama-sama terhadap Kinerja Pegawai Kantor Desa Abang.

\section{METODE}

Adapun rancangan atau desain penelitian ini, dapat digambarkan sebagai berikut :

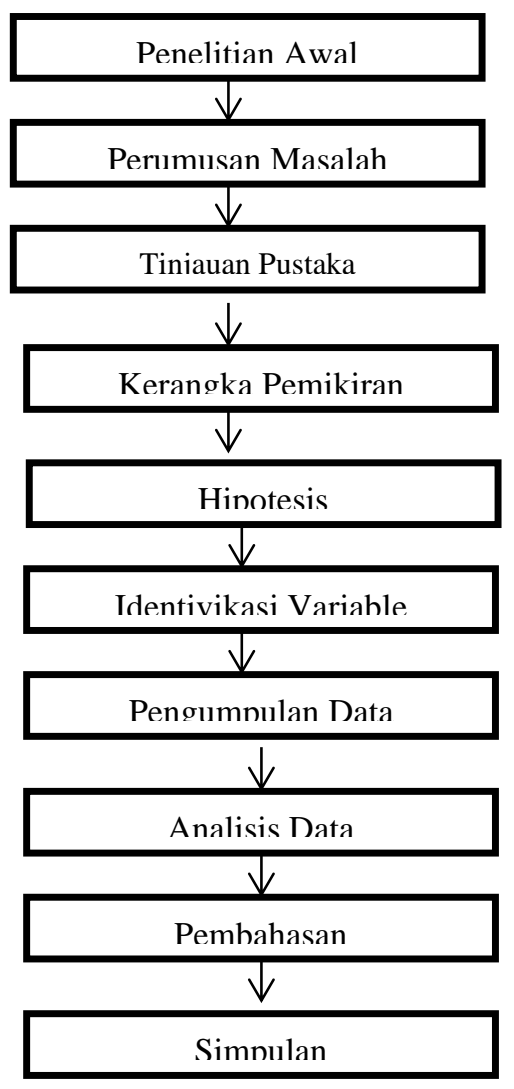


Populasi dalam penelitian ini adalah pegawai Kantor Desa Abang yang berjumlah 30 orang.Teknik pengambilan sampel dalam penelitian ini menggunakan total sampling. Total Sampling adalah teknik pengambilan sampel dimana jumlah sampel sama denga populasi. Alasan mengambil total samplingkarena jumlah populasi yang kurang dari 100 seluruh populasi dijadikan sampel. Sampel yang di ambil dari penelitian ini adalah 30 orang.
Sumber data dalam penelitian ini dapat dibedakan menjadi dua, yaitu sumber data primer dan sumber data sekunder. Data primer diperoleh di lapangan secara langsung oleh peneliti dalam bentuk kuesioner (angket), wawancara, dan observasi (pengamatan). Data sekunder diperoleh peneliti dalam bentuk dokumentasi melalui studi pustaka dan sumber-sumber lain yang mendukung penelitian ini.

Penelitian ini metode yang digunakan mengumpulkan data adalah:

Tabel 4.5

Batasan Klasifikasi

\begin{tabular}{|c|l|}
\hline Rata-rata & \multicolumn{1}{|c|}{ Klasifikasi } \\
\hline $4,21-5$ & Sangat baik \\
\hline $3,41-4,2$ & Baik \\
\hline $2,61-3,4$ & Cukup \\
\hline $1,81-2,6$ & Tidak baik \\
\hline $1-1,80$ & Sangat tidak baik \\
\hline
\end{tabular}

Sumber : Data primer yang diolah, 2019

Berdasarkan penyebaran terhadap 30 responden dapat kesioner dari Motivasi Kerja (X1) diketahui sebagai berikut:

Tabel 4.6

Ringkasan Hasil Penyebaran Kusioner Variabel Motivasi Kerja

\begin{tabular}{|l|l|c|c|}
\hline No. & \multicolumn{1}{|c|}{ Kriteria } & Jumlah & Persentase (\%) \\
\hline 1 & Sangat baik & 14 & $46,67 \%$ \\
\hline 2 & Baik & 14 & $46,67 \%$ \\
\hline 3 & Cukup & 2 & $6,66 \%$ \\
\hline 4 & Tidak baik & 0 & $0 \%$ \\
\hline 5 & Sangat tidak baik & 0 & $0 \%$ \\
\hline \multicolumn{2}{|c|}{ Jumlah } & $\mathbf{3 0}$ & $\mathbf{1 0 0 \%}$ \\
\hline
\end{tabular}

Sumber : Data primer yang diolah, 2019

Secara keseluruhan motivasi kerja di Kantor Desa Abang,
Kecamatan Abang, Karangasem tergolong Baik. Hal itu terlihat 
apabila dirata-ratakan hasilnya mencapai 4,2 (kategori Baik).

Berdasarkan penyebaran kesioner dari Lingkungan Kerja (X2) terhadap 30 responden dapat diketahui sebagai berikut:

Tabel 4.7

Ringkasan Hasil Penyebaran Kusioner Variabel Lingkungan Kerja

\begin{tabular}{|l|l|l|l|}
\hline No. & \multicolumn{1}{|c|}{ Kriteria } & Jumlah & \multicolumn{1}{c|}{ Persentase (\%) } \\
\hline 1 & Sangat baik & 12 & $40,00 \%$ \\
\hline 2 & Baik & 17 & $56,67 \%$ \\
\hline 3 & Cukup & 1 & $3,33 \%$ \\
\hline 4 & Tidak baik & 0 & $0 \%$ \\
\hline 5 & Sangat tidak baik & 0 & $0 \%$ \\
\hline Jumlah & $\mathbf{3 0}$ & $\mathbf{1 0 0 \%}$ \\
\hline
\end{tabular}

Sumber : Data primer yang diolah, 2019

Secara keseluruhan Lingkungan kerja di Kantor Desa Abang, Kecamatan Abang, Karangasem tergolong Baik. Hal itu terlihat apabila dirata-ratakan hasilnya mencapai 4,1 (kategori Baik).
Berdasarkan penyebaran kesioner dari Kinerja Pegawai (Y) terhadap 30 responden dapat diketahui sebagai berikut:

Tabel 4.8

Ringkasan Hasil Penyebaran Kusioner

Variabel Kinerja Pegawai

\begin{tabular}{|l|l|c|c|}
\hline No. & \multicolumn{1}{|c|}{ Kriteria } & Jumlah & Persentase (\%) \\
\hline 1 & Sangat baik & 16 & $53,33 \%$ \\
\hline 2 & Baik & 14 & $46,67 \%$ \\
\hline 3 & Cukup & 0 & $0 \%$ \\
\hline 4 & Tidak baik & 0 & $0 \%$ \\
\hline 5 & Sangat tidak baik & 0 & $0 \%$ \\
\hline \multicolumn{2}{|c|}{ Jumlah } & $\mathbf{3 0}$ & $\mathbf{1 0 0 \%}$ \\
\hline
\end{tabular}

Sumber : Data primer yang diolah, 2019

Secara keseluruhan Kinerja Pegawai di Kantor Desa Abang, Kecamatan Abang, Karangasem tergolong Sangat Baik. Hal itu terlihat apabila dirata-ratakan hasilnya mencapai 4,4 (kategori Sangat Baik).। Pengaruh Motivasi Kerja (X1) dan Lingkungan Kerja (X2) terhadap
Kinerja Pegawai (Y) dapat diketahui dengan menggunakan analisis regresi, dalam hal ini digunakan regresi linier berganda. Hal ini dilakukan mengingat jumlah variabel berjumlah tiga variabel, dengan bantuan program SPSS for windows 
21,0 diperoleh hasil sebagai berikut:

Tabel 4.14

Hasil Analisis Regresi Linier Berganda

\begin{tabular}{|c|c|c|c|c|c|}
\hline \multirow[b]{2}{*}{ Model } & \multicolumn{2}{|c|}{ Unstandardized } & \multirow{2}{*}{\begin{tabular}{|c|}
$\begin{array}{c}\text { Standar } \\
\text { dized }\end{array}$ \\
Beta
\end{tabular}} & \multirow[b]{2}{*}{$\mathrm{t}$} & \multirow[b]{2}{*}{ Sig. } \\
\hline & B & $\begin{array}{l}\text { Std. } \\
\text { Error }\end{array}$ & & & \\
\hline 1 (Constant) & 5.323 & 2.197 & & 2.423 & .022 \\
\hline Motivasi & .306 & .123 & .350 & 2.488 & .019 \\
\hline LingkunganKerja & .305 & .077 & .558 & 3.972 & .000 \\
\hline
\end{tabular}

Sumber : Data pengolahan SPSS, 2019

$$
\begin{array}{rr}
Y=a+b_{1} X_{1+} & b_{2} X_{2} \\
\hline a & =5,323 \\
b 1 & =0,306 \\
b 2 & =0,305
\end{array}
$$

Sehingga

persamaan

regresinya adalah :

$\mathrm{Y}=5,323+0,306 \mathrm{X} 1+0,305 \mathrm{X} 2$

Berdasarkan hasil regresi ini dapat dijelaskan bahwa :

a) $\mathrm{a}=5,323$, jika nilai Motivasi dan Lingkungan Kerja sebesar nol atau tidak memiliki nilai sama sekali, maka Kinerja Pegawai (Y) akan memiliki nilai sebesar 5,323

b) $\mathrm{b} 1=0,306$, merupakan koefisien arah regresi linier yang positif, artinya bahwa setiap Motivasi Kerja (X1) sebesar satu, maka Kinerja Pegawai (Y) cenderung bertambah sebesar 0,306 dengan asumsi Lingkungan Kerja (X2) dianggap konstan.

c) $\mathrm{b} 2=0,305$, merupakan koefisien arah regresi linier yang positif, artinya bahwa setiap Lingkungan Kerja (X2) sebesar satu, maka Kinerja Pegawai (Y) cenderung bertambah sebesar 0,305 dengan asumsi Motivasi Kerja (X1), dianggap konstan.

Menggunakan program SPSS for windows 21.0 diperoleh hasil korelasi untuk pengaruh Motivasi kerja (X1) dan Lingkungan Kerja (X2) terhadap Kinerja Pegawai (Y) seperti pada tabel sebagai berikut.

Tabel 4.16

Hasil Analisis Korelasi Berganda 


\begin{tabular}{|l|r|r|r|r|}
\hline Model & \multicolumn{1}{|c|}{ R } & R Square & $\begin{array}{c}\text { Adjusted R } \\
\text { Square }\end{array}$ & Durbin-Watson \\
\hline 1 & $.825^{\mathrm{a}}$ & .681 & .657 & 2.273 \\
\hline
\end{tabular}

Sumber : Data pengolahan SPSS, 2019

$r=0.825$. Hal ini sesuai dengan kriteria yang diterangkan sebelumnya : Jika $r>0$ artinya telah terjadi hubungan yang linier positif, yaitu makin besar nilai variabel $\mathrm{X}$, maka makin besar pula nilai variabel $\mathrm{Y}$ atau makin kecil nilai variabel $\mathrm{X}$ makin kecil pula nilai variabel Y.

Dari panduan tabel koefisien korelasi, dapat dijelaskan bahwa terdapat hubungan positif antara pengaruh Motivasi (X1) dan Lingkungan Kerja (X2) terhadap Kinerja Pegawai (Y) yaitu terdapat hubungan yang tinggi atau sangat kuat, karena terletak antara 0,800 sampai dengan 1,199. Artinya semakin besar motivasi dan baiknya lingkungan kerja yang diberikan, maka tinggi pula kinerja pegawai.

Melalui

persamaan

determinasi sebagai berikut.

$D=r 2 \times 100 \%$

Dari perhitungan persamaan determinasi tersebut, diperoleh hasil sebagai berikut :

$$
\begin{aligned}
\mathrm{D} & =\mathrm{r}^{2} \times 100 \% \\
& =0,681 \times 100 \% \\
& =68,10 \%
\end{aligned}
$$

Besar pengaruh Motivasi dan Lingkungan Kerja terhadap Kinerja Pegawai, mempunyai pengaruh yang cukup kuat, yaitu $68,10 \%$, dalam upaya meningkatkan kinerja Pegawai., sedangkan sisanya $31,90 \%$ dipengaruhi faktor lain yang tidak dibahas dalam penelitian ini.

Analisis t-test (uji t) adalah suatu analisis untuk menguji apakah koefisien korelasi yang diperoleh di atas telah signifikan atau tidak. Adapun langkah - langkah pengujian tersebut adalah sebagai berikut:

a. Perumusan hipotesis

Hipotesis yang diuji adalah Pengaruh Motivasi (X1) dan Lingkungan Kerja (X2) Terhadap Kinerja Pegawai (Y) di Kantor Desa Abang, Kecamatan Abang, Kabupaten Karangasem. Sesuai dengan hipotesis tersebut maka dapat dirumuskan hipotesis kerjanya sebagai berikut :

1) Ho : $b=0$ artinya Motivasi (X1) tidak berpengaruh terhadap Kinerja Pegawai (Y) Kantor Desa Abang, Kecamatan Abang, Kabupaten Karangasem

Hi : $b>0$ artinya Lingkungan Kerja (X1) berpengaruh terhadap Kinerja Pegawai (Y) Kantor Desa Abang, Kecamatan Abang, Kabupaten Karangasem

2) Ho : $b=0$ artinya Lingkungan Kerja (X2) tidak berpengaruh terhadap Kinerja Pegawai (Y) Kantor Desa Abang, Kecamatan Abang,Kabupaten Karangasem 
$\mathrm{Hi}: \mathrm{b}>0$ artinya Lingkungan Kerja (X2) berpengaruh terhadap Kinerja Pegawai (Y) Kantor Desa Abang, Kecamatan Abang,Kabupaten

Karangasem

b. Penentuan statistik tabel

Sesuai dengan hipotesis alternatif (Ha) yang diajukan, maka dalam pengujian ini digunakan uji satu pihak yaitu uji pihak kanan dengan $\mathrm{t}-$ tabel $=\mathrm{t}_{(\alpha, \mathrm{df})}$. $\alpha($ tingkat kesalahan) yang digunakan adalah 5\% dan df (derajat kebebasan) adalah $\mathrm{n}-\mathrm{k}$. Perhitungan untuk derajat kebebasan (db) yaitu dapat dicari dengan rumus:

$$
\begin{aligned}
\hline \mathrm{df} & =\mathrm{N}-2 \\
& =30-2 \\
& =28
\end{aligned}
$$

$\mathrm{df}=28$ dalam taraf signifikasi $5 \%$ maka diperoleh $\mathrm{t}$ tabel $=2,045$

c. Kriteria penolakan atau penerimaan hipotesis

Adapun kriteria penerimaan atau penolakan hipotesis yang diajukan diatas adalah sebagai berikut :

Ho diterima dan $\mathrm{Hi}$ ditolak apabila $\mathrm{t}$ - hitung $\leq \mathrm{t}-$ tabel

Ho ditolak dan $\mathrm{Hi}$ diterima apabila $\mathrm{t}$ - hiutng $>\mathrm{t}$ - table.

Melalui analisis yamh dilakukan tentang pengaruh Motivasi Kerja terhadap Kinerja Pegawaidiperoleh t-test sebesar 5.228 pada daerah penolakan Ho, dimana t- hitung lebih besar daripada t-tabel, dengan demikian Hipotesis menyatakan bahwa terdapat hubungan yang positif antara Motivasi Kerja terhadap Kinerja Pegawai dengan hubungan yang kuat. Berdasarkan atas keseluruhan hasil pengujian dan uraian gambar diatas maka dapat disimpulkan bahwa Motivasi kerja (X1) secara parsial berpengaruh positif terhadap Kinerja Pegawai (Y) positif dan signifikan karena $\mathrm{t}-$ hitung $>\mathrm{t}-$ tabel yaitu $5.228>2,045$, sehingga Ho ditolak dan Hi diterima.

Pengaruh Lingkungan Kerja terhadap Kinerja Pegawai diperoleh ttest sebesar 6.581pada daerah penolakan Ho, dimana t-hitung lebih besar daripada t-tabel, dengan demikian Hipotesis menyatakan bahwa terdapat hubungan yang positif antara Lingkungan Kerja terhadap Kinerja Pegawai dengan hubungan yang kuat. Berdasarkan atas keseluruhan hasil pengujian dan uraian gambar diatas maka dapat disimpulkan bahwa Lingkungan Kerja (X2) secara parsial berpengaruh positif terhadap Kinerja Pegawai (Y) positif dan signifikan, karena $\mathrm{t}-$ hitung $>\mathrm{t}-$ tabel yaitu 6.581> 2,045, sehingga Ho ditolak dan Hi diterima.

Dari kedua analisis t-test di atas, dapat dijelaskan bahwa Motivasi Kerja dan Lingkungan Kerja memiliki pengaruh yang kuat terhadap Kinerja Pegawai.

Melalui bantuan program SPSS for windows 21,0 diperoleh f-test = 28,766 sesuai dengan table berikut

Tabel 4.19

Hasil Analisis F-test 
ANOVA ${ }^{b}$

\begin{tabular}{|ll|r|r|r|r|r|}
\hline \multicolumn{2}{|l|}{ Model } & \multicolumn{1}{|c|}{$\begin{array}{c}\text { Sum of } \\
\text { Squares }\end{array}$} & Df & Mean Square & F & \multicolumn{1}{c|}{ Sig. } \\
\hline 1 & Regression & 45.850 & 2 & 22.925 & 28.766 & $.000^{\mathrm{a}}$ \\
& Residual & 21.517 & 27 & .797 & & \\
& Total & 67.367 & 29 & & & \\
\hline
\end{tabular}

a. Predictors: (Constant), LingkunganKerja, Motivasi

b. Dependent Variable: Kinerja

Sumber : Data pengolahan SPSS, 2019 
Jurnal Satyagraha, Vol. 02, No. 02, Agustus 2019 - Januari 2020 ISSN :2620-6358

Perhitungan df1 dan df2 menurut Sugiono (2017 : 192) adalah sebagai berikut :

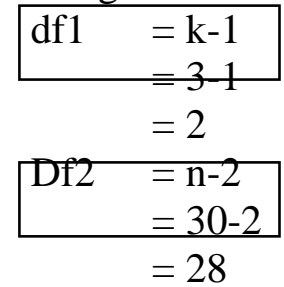

Keterangan :

Df1= derajat kebebasan penyebut

Df2= derajat kebebasan pembilang

$\mathrm{K}=$ Jumlah variable

$\mathrm{n}=$ jumlah sampel

(Sugiyono, $2007:$ 192)

Signifikan sebesar 5\% dengan df1 = 2 dan df2 $=28$, maka f-tabel adalah 3,34

Melihat $F_{\text {test }}>\mathrm{F}$ tabel dan nilai signifikansinya $<0,05$, maka ada pengaruh antara bebas terhadap variabel terikat, dengan demikian pengujian model tersebut dikatakan baik.

Melihat hasil dari analisis di atas, maka diperoleh f-test sebesar 28,766 pada daerah penolakan Ho, dimana f-test lebih besar daripada f-tabel, dengan demikian Hipotesis menyatakan bahwa terdapat hubungan yang positif antara Motivasi Kerja dan Lingkungan Kerja terhadap Kinerja Pegawai dengan hubungan yang kuat.

\section{SIMPULAN DAN SARAN}

Adapun kesimpulan yang dapat diambil adfalah : 1) Secara parsial terdapat hubungan yang positif antara Motivasi kerja terhadap Kinerja Pegawai dengan hubungan yang kuat. 2) Lingkungan Kerja (X2) secara parsial berpengaruh positif terhadap Kinerja Pegawai (Y) positif dan signifikan, karena $\mathrm{t}$ - hitung > $\mathrm{t}$ - tabel yaitu 5,323>2,045, sehingga Ho ditolak dan $\mathrm{Hi}$ diterima. 3) Secara simultan terdapat hubungan positif dan signifikan antara motivasi kerja dan lingkungan kerja terhadap kinerja pegawai di Kantor Desa Abang Kecamatan Abang Kabupaten Karangasem.

Saran-saran mengacu pada hasil penelitian dan berupa tindakan praktis, sebutkan untuk siapa dan untuk apa saran ditujukan. Ditulis dalam bentuk essay, bukan dalam bentuk numerikal.

Kesempatan ini disarankan kepada pihak Organisasi hendaknya tetap memperhatikan motivasi kerja dan bagaimana pola Lingkungan Kerja untuk meningkatkan Kinerja Pegawai. Pentingnya meningkatkan motivasi kerja serta memperhatikan lingkungan kerja yang kondusif dalam upaya meningkatkan kinerja Organisasi dalam menambah membangun Organisasi.

\section{UCAPAN TERIMA KASIH}

Ucapan terima kasih diberikan kepada :

1. Bapak DR. Shri I Gusti Ngurah Arya Wedakarna Mahendradatta Wedasteraputra Suyasa III, SE, M( Tru ), M.Si selaku Dewan Pembina Universitas Mahendradatta Bali.

2. Bapak Shri I Gusti Ngurah Wira Wedawitry. W.V.M.S.Sos, SH, MH selaku Ketua Yayasan Universitas Mahendradatta Bali.

3. Ibu DR. Putri Anggreni, SE, M.BA, M.Pd, selaku Rektor Universitas Mahendradatta Bali.

4. Bapak I Dewa Nyoman Usadha, SE, M.M, selaku Dekan Fakultas Ekonomi Universitas Mahendradatta Bali.

5. Bapak Drs I Made Arjana, M.Si, selaku Dosen Pembimbing I yang senantiasa dengan sabar membimbing, memberi 
Jurnal Satyagraha, Vol. 02, No. 02, Agustus 2019 - Januari 2020 ISSN :2620-6358

petunjuk dan pengarahan dalam penyusunan skripsi ini.

6. Bapak Drs Ngurah Arya Suryadhana, M.Si, selaku Dosen Pembimbing II yang senantiasa dengan sabar membimbing, memberi petunjuk dan pengarahan dalam penyusunan skripsi ini.

7. Seluruh Staff dan Pegawai Kantor Desa Abang yang telah membantu pelaksanaan penelitian skripsi.

8. Sahabat dan teman-teman yang telah membantu selama pelaksanaan skripsi.

9. Orang Tua tercinta yang telah mendukung dan saudara-saudara saya yang telah memberikan semangat dan motivasi dalam penyusunan skripsi ini.

\section{DAFTARPUSTAKA}

AAAnwarPrabu Mangkunegara. 2009.

Manajemen Sumber Daya

Manusia. Bandung: PT. Remaja

Rosdakarya

Abdullah, Sandy. 2013. Penilaian Kinerja Profesi Guru dan Angka Kreditnya. Yogyakarta: Gava Media

Alex S. Nitisemito, 2010. Manajemen personalia Manajemen Sumber Daya Manusia. Edisi Ketiga. Jakarta : Ghalia Indonesia.

Ali, Hasan. (2008). Marketing. Yogyakarta. Media Pressindo.

angun, Wilson. 2012. "Manajemen Sumber Daya Manusia". Jakarta: Erlangga.
Arikunto, Suharsimi. 2006. Prosedur Penelitian Suatu Pendekatan Praktik. Jakarta: Rineka Cipta.

Budiharto, Widodo.2010. Robotika : Teori + Implementasi. Yogyakarta : Andi.

Coulter, Mary\&Stephen, Robbins.P. (1999). Management. Sixth Edition. PT. Prehallindo,. Jakarta.

Fahmi, Irham.( 2010). Manajemen Kinerja. Bandung: Alfabet.

Ghozali, Imam, 2009, Aplikasi Analisis Multivariate Dengan Program SPSS,. Semarang: Badan Penerbit Universitas Diponegoro, Vol.100-125.

G. Saydam, 1996. Manajemen Sumber Daya Manusia (Human Resources Management) Suatu Pendekatan Mikro (Dalam Tanya Jawab). Djambatan, Jakarta.

Hasibuan, Malayu. 2012. "Manajemen Sumber Daya manusia". Jakarta: PT Bumi. Aksara.

Mahsun. 2011. Metode Penelitian Bahasa: Tahapan Strategi, Metode, dan Tekniknya. Jakarta: Raja Grafindo Persada.

Mathis, R.L. \& J.H. Jackson. 2006. Human Resource Management: Manajemen Sumber. Daya Manusia. Terjemahan Dian Angelia. Salemba Empat : Jakarta 
Jurnal Satyagraha, Vol. 02, No. 02, Agustus 2019 - Januari 2020 ISSN :2620-6358

Nazir, Moh. 2005. Metode Penelitian. Jakarta: Ghalia Indonesia.

Robbins, Stephen P. 2001. Perilaku Organisasi: Konsep, Kontroversi, Aplikasi, Jilid. 1, Edisi 8, Prenhallindo, Jakarta.

Sari, Emilia Noviani Asta. 2009. Pengaruh Lingkungan Kerja Terhadap Kinerja Karyawan Bagian Produksi PT Glory Industrial Semarang II. Skripsi. Semarang: Universitas Negeri Semarang.

Sartika Hayulinda. 2012. “Analisis Pengaruh Motivasi dan Lingkungan Kerja Terhadap Kinerja Karyawan pada PT Sinar Galesong Pratama Makassar". Skripsi. Makasar: Fakultas Ekonomi dan Bisnis Universitas Hasaniddin.

Sedarmayanti.2009. Sumber Daya Manusia dan Produktivitas Kerja. Bandung: CV. Mandar Maju.

Siagian, Sondang P, 2003. Teori dan Praktek Kepemimpinan. PT Rineka Cipta. Jakarta.

Siagian, 2013, Manajemen Sumber daya Manusia, Bumi aksara, jakarta.

Sofyandi, Herman dan Iwa Garniwa. 2007. Perilaku Organisasi Yogyakarta: Graha. Ilmu.

Sugianto, 2008. Penelitian Pendidikan. Bandung: Alfabeta.
Sugiyono, 2013, Metodelogi Penelitian Kuantitatif, Kualitatif Dan R\&D. (Bandung: ALFABETA)

Supranto, J. (2000). Statistik Teori dan Aplikasi. Jilid 1 Edisi 6. Erlanggga : Jakarta.

Supriyono, Rakhmat.2010.Desain Komunikasi Visual : Teori dan Aplikasi. Yogyakarta: Andi.

Winardi. 2002. Motivasi dan Pemotivasian dalam Manajemen. Jakarta: Raja Grafindo

Wirawan, 2009, Evaluasi Kinerja Manajemn Sumberd Daya Manusia, Jakarta : Salemba Empat.

Zainur Roziqin. 2010. Kepuasan Kerja. Malang: Averroes Press. 